\title{
A Látrányi Puszta Természetvédelmi Terület aktuális vegetációtérképe
}

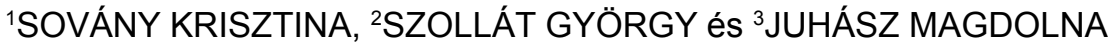 \\ ${ }^{1}$ Kaposvári Egyetem, Természetvédelmi Tanszék \\ H-7400 Kaposvár, Guba S. u. 40., e-mail: sovanykriszti@gmail.com \\ ${ }^{2}$ Kaposvári Egyetem, Természetvédelmi Tanszék \\ H-7400 Kaposvár, Guba S. u. 40., e-mail: gyorgy.szollat@gmail.com \\ ${ }^{3}$ Rippl-Rónai Múzeum \\ H-7400 Kaposvár, Fő u. 101., e-mail: juhasz@smmi.hu
}

\begin{abstract}
SovÁny, K., Szollát, Gy. \& JuHÁsz, M.: Actual Vegetation Map of Látrányi Puszta Nature Conservation Area (Hungary).

Abstract: The aim of this survey was to create an actual, very particular and GIS-based vegetation map of the Látrányi Puszta Nature Conservation Area. As a main result of the survey 26 several habitats were detected in 94 vegetation patches or patch-groups. Mostly the woodless habitats are the notablest ones, like rich fens, open sand steppes or some more natural stands of closed sand steppes.
\end{abstract}

Keywords: GIS, vegetation map, Látrányi Puszta, ÁNÉR

\section{Bevezetés}

A Balaton-medence peremén fekvő, 220,7 hektár területű Látrányi Puszta Természetvédelmi Terület 1992ben vált országos jelentőségü védett területté. Kiemelkedő növénytani ritkaságai mellett állatvilága és tájképi értékei is jellegzetesek. A Dél-Dunántúlon és különösen a Balaton-térségben ma már kevés ilyen épen fennmaradt, változatos élőhelykomplexum található. Bár a legtöbb kutatás alapjául szolgáló Magyarország kistájainak katasztere (MAROsı szerk. 1990) és annak újabb kiadása (DöVÉNYı Szerk. 2010) is Nyugat-Külső-Somogyhoz tartozóként jelöli, a terület felszínfejlödésének alakulása, alapkőzete, talajtani, klimatikus és botanikai adottságai alapján a Balaton-medencéhez tartozik. Ide sorolták MolNÁr Csaba és munkatársai is hazánk vegetációs tájainak meghatározásánál (MoLNÁR Cs. et al. 2008). A Látrányi Puszta helyzete különleges, mert tájhatáron fekszik, Külső-Somogy lösszel fedett dombvidéke és a Balaton-medence határán. Külső-somogyi meridionális hátak fogják közre azt a völgyet, amelynek északi részén található a vizsgált terület. Éppen ennek köszönhető a változatos élőhelykomplexum kialakulása, ugyanis az átszivárgásos lápi élöhelyek vize nagyrészt a dombsági pannon rétegekből származik. A Balaton déli partján lévő, a tóhoz kifutó meridionális völgyek tölcsérszerü öblözeteinek alapkőzete homok, így tájfejlődésileg már a Balaton-medencéhez tartoznak. E térség növényzetét DeBreCZY (1981), SZALóKY és BódIs (2004) valamint KovÁcs (1955) vizsgálta, a tó és a Látrányi Puszta területének egykori kapcsolatára pedig IHRIG (1973) és ZLINSZKY (2011) világít rá. A legjellegzetesebb élőhelytípusok - a láprétek és homoki gyepek - jellemzőiről hazánk más területeiről származó alapvetéseket LÁJer (1998a, 2006), LendVAl (1990), MolnÁr Zs. et al (2008 a,b) és KovÁcs (1958) munkái tartalmaznak.
Maga a Látrányi Puszta területe botanikailag kevéssé kutatott. Szórványos adatokat LÁJeR (1998b,c), és RozNER et al. (2011) munkáiban találhatunk. Az eddigi legrészletesebb vizsgálatok az ezredforduló környékén zajlottak a természetvédelmi kezelési terv megalapozásaként. A felmérés eredményei a Natura Somogyiensis 5. tanulmánykötetében kerültek publikálásra (ÁBRAHÁM szerk., 2003), amelyben a botanikai fejezet LÁJER (2003) nevéhez kötődik. Ez a fejezet mára aktualizálásra és némi pontosításra szorult az azóta kidolgozásra került Általános Nemzeti Élőhely-osztályozási Rendszer (ÁNÉR) és modern térinformatikai módszerek alkalmazása révén.

\section{Anyag és módszer}

A terepi munkálatok keretében alapos és rendszeres területbejárást végeztünk 2010. április és 2012. augusztus között. Az egyes élőhelyfoltok kiterjedése egy Garmin Geko 201, és egy Garmin Geko 301 típusú GPS készülék segítségével, ún. track-ek felvételével került rögzítésre. A faültetvények esetében a terület erdészeti üzemtervi térképét, valamint a területről 2005-ben készült légifotót vettük alapul, mivel a vegetációs időszak elörehaladtával a lombozat árnyékolása negatívan befolyásolta a GPS készülék pontosságát. A track-eket Oziexplorer program segítségével vittük számítógépre, ugyanezen program segítségével ESRI Shape File-okba mentettük, majd ArcView GIS 3.1 típusú szoftverrel dolgoztuk fel.

$A z$ élőhelyek kategorizálásának tekintetében az ÁNÉR legújabb felosztását (BöLöNı et al. 2011) vettük alapul, néhány esetben finomításokkal élve. Ezek a finomabb kategóriák besorolhatók az élőhely-osztályozási rendszer kategóriáiba, ugyanakkor annak osztályozási szintjénél finomabb (esetenként cönológiai) kategóriát jelentenek. A növényállományok egymástól való elkülönítésénél BARTHA et al. (2006) és BoRHIDI (2003) útmutatásait is felhasználtuk. A fajok neveit illetően $\mathrm{K}$ RÁLY (szerk., 2009) munkáját vettük alapul.

\section{Eredmények}

A felmérés eredményeként elkészült vegetációtérképen (1. ábra) összesen 94 élőhelyfoltban (foltcsoportban) 26 különböző vegetációtípust különítettünk el. $A z$ egyes növényzeti típusok által borított összterület adatokat az 1. táblázat tartalmazza. Az élőhelytípusok jellemzését az alábbiakban ismertetjük. 


\section{Lápi zsombékosok fragmentumai (B4)}

Vízállásos, alacsonyabb térszíneken előforduló élőhelytípus, állományai csak fragmentálisan találhatók meg. A legjellemzőbb állományalkotó a Carex elata, mellette néhol Carex paniculata vagy Juncus inflexus is előfordul. Gyakran Carex acutiformis alkotta nem zsombékoló magassásrétekkel övezve, vagy azokkal mozaikolva található meg. A sások mellett Iris pseudacorus, Equisetum telmateia, Solanum dulcamara, Lythrum salicaria, Mentha aquatica, Lysimachia vulgaris, Juncus articulatus valamint Typha angustifolia is előfordul. A legdélebbre található foltban Thelypteris palustris is behúzódott állományába, amely tőzegképződést és jobb vízellátást jelez. Degradáltabb részein a szárazodást jelző Calamagrostis epigeios, valamint Phragmites australis figyelhető meg. Csekély mértékben cserjésedik (Salix cinerea, Frangula alnus, Populus tremula, P. nigra).

\section{Nem zsombékoló magassásrétek (B5)}

Alacsonyabb térszínen, gyakran buckaközökben, efemer vízfolyások mentén fordulnak elő, vagy ott, ahol a homokdombok átszivárgó vizéből juthatnak némi többletvízhez. A zsombékosokkal ellentétben felszíni egyenlőtlenségek és tőzegképződés nem jellemző rájuk. Leggyakrabban a Carex acutiformis dominál, helyenként mellette a Carex riparia, míg lápi jellegü állományaiban a Juncus effusus is elöfordul. Gyakori fajai az Iris pseudacorus, Lythrum salicaria, Calystegia sepium, Eupatorium cannabinum, Cirsium rivulare. További jellemző, de kisebb egyedszámmal szereplő fajai a Cirsium canum, Sonchus palustris, Lysimachia vulgaris, Valeriana officinalis, Lycopus europaeus, Selinum carvifolia, és az üdébb jelleget jelző Filipendula ulmaria. A széleken a Sanguisorba officinalis vagy a Juncus subnodulosus is behúzódik a kiszáradó láprétekből. Állományai helyenként Salix cinereaval cserjésednek. Nagyobb problémát okoz a Phragmites australis és Solidago gigantea erőteljes terjedése.

\section{Meszes láprétek (D1)}

A jobb vízellátású, szinte állandóan nedves, mélyebb fekvésű területeken a dunántúli, sőt országos viszonylatban is ritka meszes láprétek találhatók (2. ábra). A látrányi meszes láprétek jellegzetessége, hogy a csoport névadó faja, a Carex davalliana hiányzik. Általában dominál a Juncus subnodulosus vagy a Schoenus nigricans. Helyenként a Carex hostiana, a Thelypteris palustris, valamint egyetlen foltban a Cladium mariscus jelenléte a meghatározó. Az állomány értékes volta miatt ezt a foltot indokoltnak láttuk elkülöníteni és külön ábrázolni („télisásos láprét”). Jellegzetes, ám viszonylag ritka fajai az Eriophorum latifolium, E. angustifolium. Gyakoribb a Carex flacca, Lotus siliquosus, Potentilla erecta, de előfordul benne az Epipactis palustris, Parnassia palustis, Carex panicea, Galium palustre, Cirsium palustre, Carex flava, Dactyloriza incarnata, Cirsium rivulare, Eleocharis uniglumis, Juncus inflexus, valamint az Equisetum palustre is. Folyamatos átmenetet képeznek a szomszédos kiszáradó láprétekkel, így az elkülönítésük nem könnyü. $A$ kiszáradó láprét fajai néhol áthúzódnak a meszes láprétbe: a Molinia coerulea is megtalálható állományaiban, de alárendelt szerepü. Emellett Succisa pratensis, kevés Sanguisorba officinalis és Serratula tinctoria is előfordul.

\section{Kékperjés rétek (D2)}

A kiszáradó láprét a második legnagyobb kiterjedésü fátlan élöhelytípus a területen (3. ábra). A Molinia coerulea domináns, míg a Molinia arundinacea csak ritkán, nagyméretű, a többi Molinia-egyed fölé magasodó csomókban található meg. Leggyakoribb kétszikű fajok a Succisa pratensis, Sanguisorba officinalis, Serratula tinctoria, Pulicaria dysenterica, Lotus siliquosus, Potentilla erecta és a Valeriana dioica. Viszonylag magas tőszámmal megtalálható a Parnassia palustris és a Cirsium rivulare is. Itt fordult elö legnagyobb tömegben a nedves láprétekre is jellemző Epipactis palustris. A nedves gyepeken általánosan elöforduló fajok közül a Lythrum salicaria, Lysimachia vulgaris, Cirsium canum, Eupatorium cannabinum, Silene vulgaris emlithető meg. A kiszáradó láprétek és homoki sztyepprétek határát legjobban a Scirpoides holoschoenus jelezte.

A kiszáradó láprétek Látrányban is gyakran képeznek átmeneti állományokat homoki sztyepprétekkel, illetve meszes láprétekkel. A sztyeppesedő, homoki sztyepprétek felé mutató átmeneti állományaik kevert jellegük ellenére viszonylag jól elkülönülnek a kiszáradó láprétektől és a homoki sztyepprétektől is. Általában kissé kiemelkedő homokdombokon vagy azok környezetében találhatók. Sztyeppfajai a Betonica officinalis, Festuca rupicola, Brachypodium pinnatum, Chrysopogon gryllus, míg kiszáradó lápréti fajai a Molinia coerulea, Sanguisorba officinalis, Carex flacca, Succisa pratensis. Néhol akár a Dianthus superbus is előfordulhat. Gyakori a Carex hirta, Centaurea pannonica syn. C. jacea ssp. angustifolia, Galium verum, Eryngium campestre, Plantago lanceolata, Hypericum perforatum, Prunus spinosa. Kisebb egyedszámban megfigyelhető fajai a Scabiosa ochroleuca, Agrimonia eupatoria, Teucrium chamaedrys, Hieracium echioides, Pseudolysimachion spicatum, Filipendula vulgaris, Carlina vulgaris, Achillea asplenifolia, Ononis spinosa, Frangula alnus. Üdébb termőhelyet kedvelő fajai a Lotus siliquosus és a foltok szélein megtalálható Scirpoides holoschoenus.

A vegetációtérképen sötét olajzöld színnel jelölt folt a meszes láprétekkel való átmenetet képviseli. Nem sorolható egyértelműen sem a meszes láprétek, sem a kiszáradó láprétek csoportjába. Gyepje még alacsony, a lápi karakterü Carex hostiana megtalálható benne, azonban a Schoenus nigricans zsombékjai letörpülnek, és a Potentilla erecta mennyisége is lecsökken. Több kékperjés elem is megjelenik benne, úgymint a Sanguisorba officinalis, Succisa pratensis, Carex flacca.

Kiszáradó lápréteknek vannak olyan részletei is, ahol a Schoenus nigricans nagyobb sürüségű előfordulását figyeltük meg. Ezek a foltok nem mutattak üde lápréti jelleget, tehát nem sorolhattuk őket a meszes láprétek közé, azonban kiterjedésüket a kiszáradó láprétek kategóriáján belül világosszürke színnel jelölve rögzítettük, amelynek okára a későbbiekben még kitérünk. 


\section{A LÁTRÁNYI PUSZTA TERMÉSZETVÉDELMI TERÜLET AKTUÁLIS VEGETÁCIÓTÉRKÉPE}

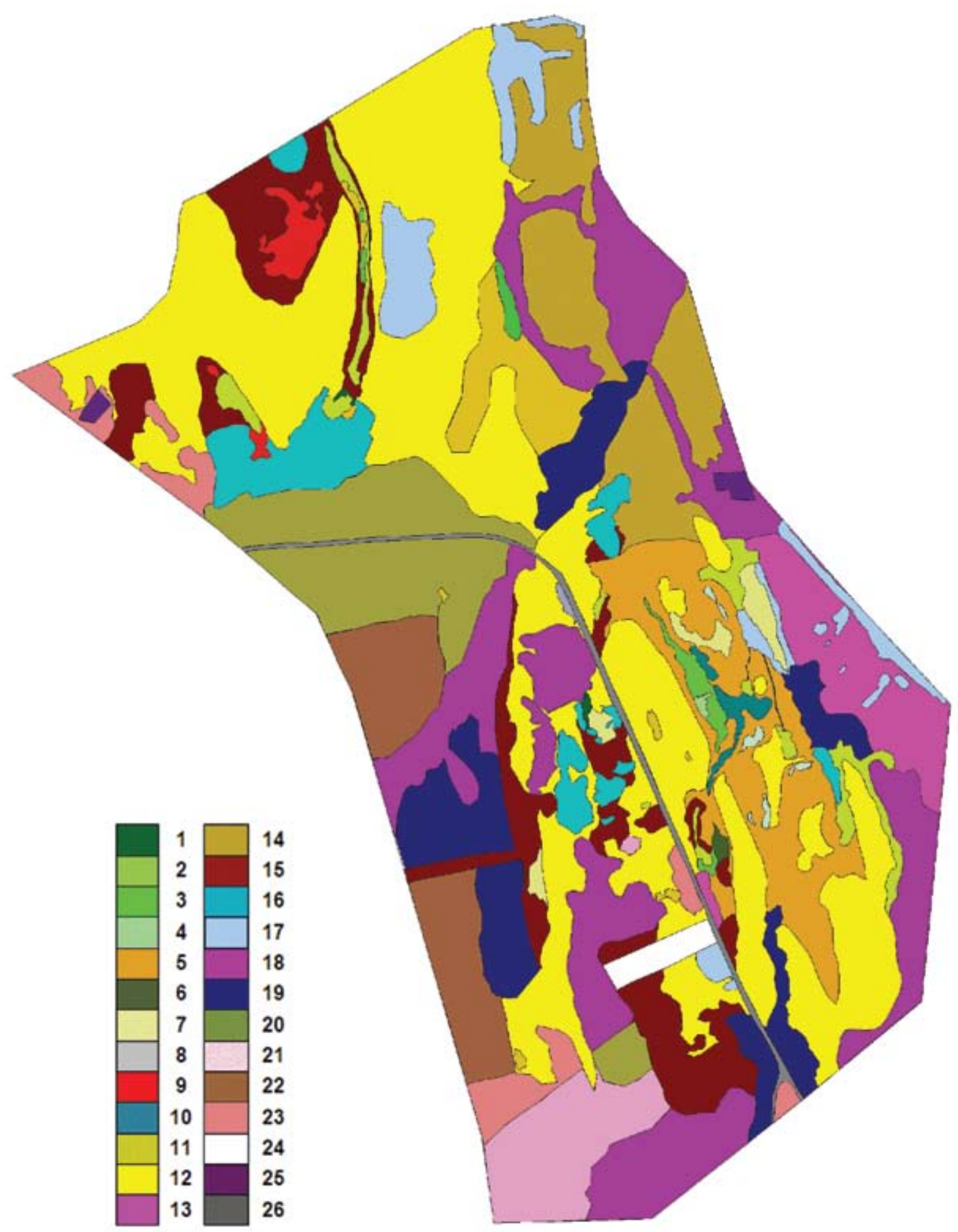

1. ábra. A Látrányi Puszta Természetvédelmi Terület aktuális vegetációtérképe.

1. Lápi zsombékosok; 2. Nem zsombékoló magassásrétek; 3. Meszes láprétek; 4. Télisásos láprét; 5. Kiszáradó láprétek; 6. Meszes láprét-kiszáradó láprét átmenetek; 7. Sztyeppesedő kiszáradó láprétek; 8. Schoenus nigricans nagyarányú előfordulásával jellemezhető kiszáradó láprétek; 9. Mocsárrétek; 10. Lápi magaskórósok; 11. Nyílt homokpusztagyepek; 12. Homoki sztyepprétek, 13. Jellegtelen üde és nedves gyepek, magaskórósok; 14. Jellegtelen száraz és félszáraz gyepek; 15. Lágyszárú özöngyomok állományai; 16. Üde, nedves cserjések; 17. Őshonos fafajú fasorok, facsoportok; 18. Jellegtelen puhafás vagy pionír erdők; 19. Jellegtelen aljnövényzetü telepített égeresek; 20. Vegyes erdők; 21. Akácültetvények; 22. Telepített fenyvesek; 23. Nem őshonos fajok spontán állományai; 24. Extenzív szántó; 25. Tanyák, családi gazdaságok; 26. Úthálózat. 


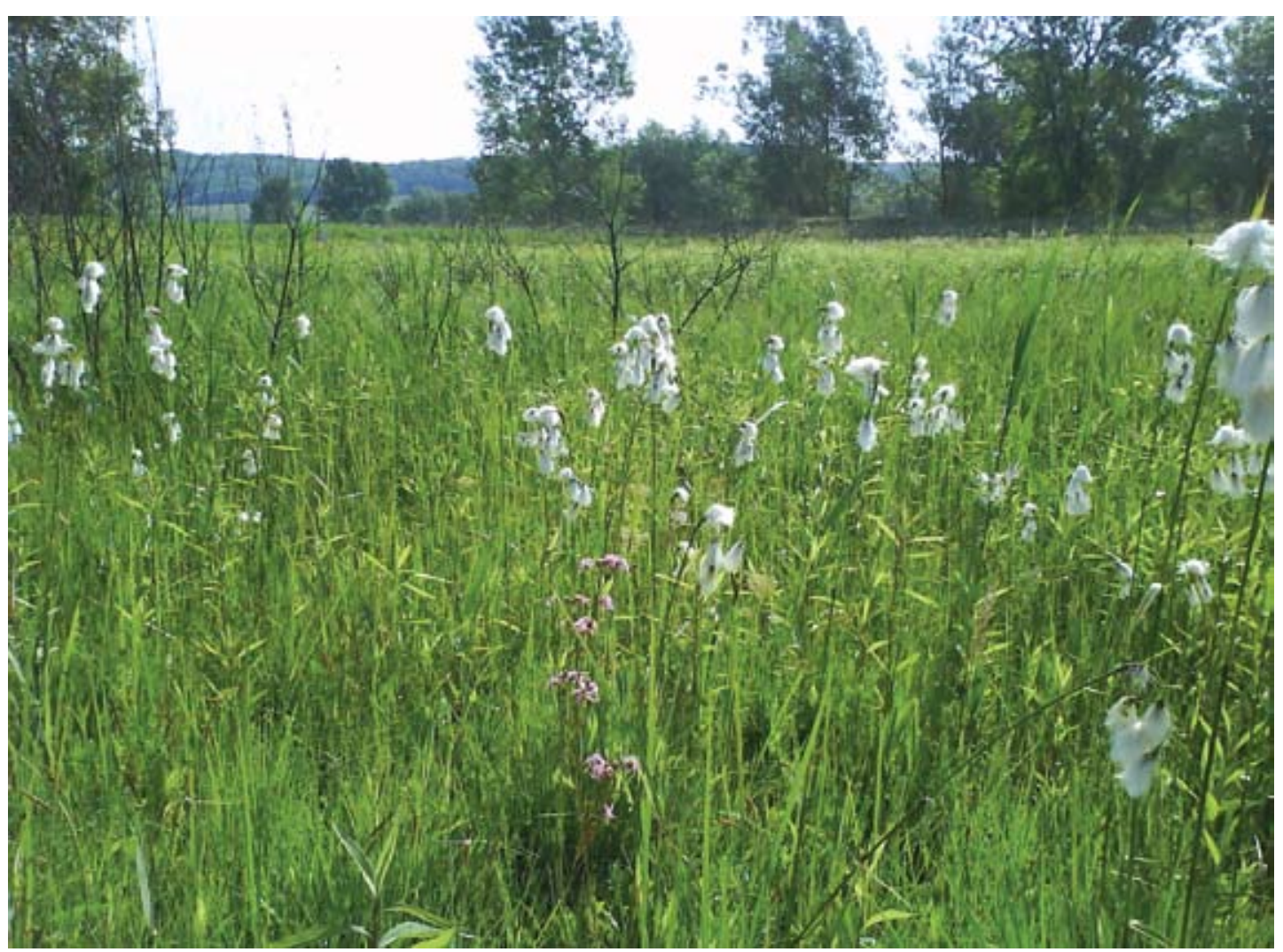

2. ábra. Meszes láprét Eriophorum latifolium-mal. (Fotó: Sovány K.)

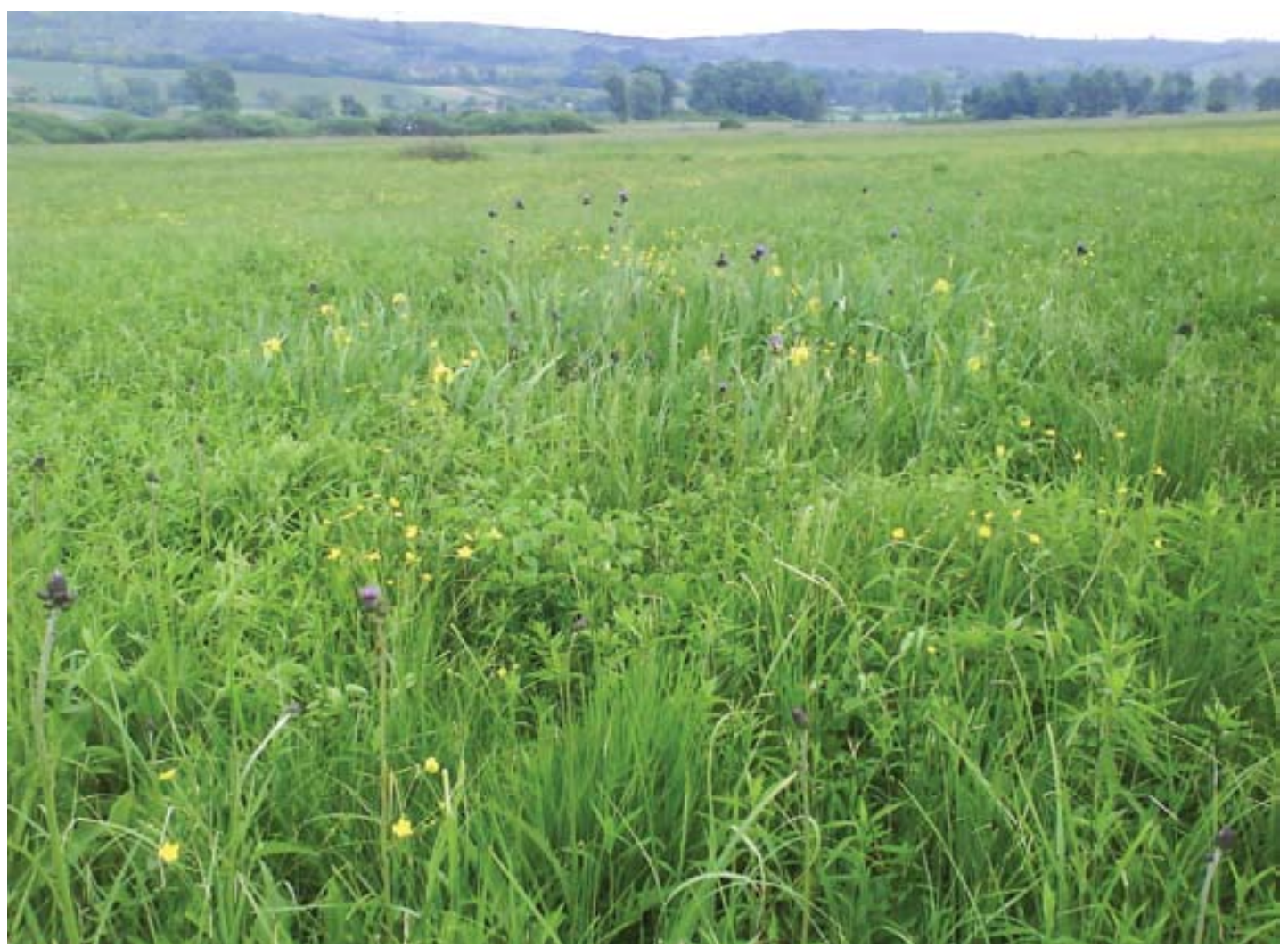

3. ábra. Fajgazdag kiszáradó láprét. (Fotó: Sovány K.) 
A helyenként nagy tömegben elöforduló Galium verum a degradáltságot illetve a szárazodást jelzi. Foltokban cserjésedik Ononis spinosa-val, Crataegus monogyna-val, valamint egyes helyeken magas borítású a Solidago gigantea. Az északabbi részeken néhol a Phragmites australis is nagy arányban megtalálható.

\section{Mocsárrétek (D34)}

A vizsgált területen a mocsárréteknek Deschampsia ceaspitosa dominanciájával jellemezhető állományai vannak, amelyek gyakran erősen gyomosak, Solidago gigantea-val szegélyezettek. A gyepes sédbúza jellegzetes csomói ugyan kijelölik az élöhelytípust, azonban a határvonal szinte soha nem éles a határos vegetációtípussal. Csak a viszonylag homogén és nagyobb összefüggő állományokat tudtuk rögzíteni. Kisebb kiterjedésü foltjai nem zsombékoló magassásréttel, üde cserjéssel, aranyvesszős állományokkal mozaikoltak. A GPS pontossága nem volt megfelelő ezek rögzítésére. $A z$ elkülönítést tovább nehezítette az állományok degradált jellege. Alapjában véve nem jellegzetes mocsárrétekröl van szó. Helyenként a Deschampsia ceaspitosa mellett megjelenik a Molinia coerulea, akár a Molinia arundinacea is, azonban a dominanciaviszonyok alapján nem beszélhetünk kiszáradó láprétről. Legnagyobb arányban a már említett fajok mellett az Agrostis alba, Pulicaria dysenterica, Sanguisorba officinalis, Rubus caesius, helyenként Equisetum ramosissimum, Selinum carvifolia fordul elö. További gyakori fajai a Lotus siliquosus, Lycopus europaeus, Achillea collina, Potentilla anserina, Eupatorium cannabinum, Galium verum, Cirsium arvense, Phragmites australis. Ritkábban előfordul a Cirsium rivulare, Lyrthum salicaria, Serratula tinctoria, Angelica sylvestris is. Természetvédelmi problémát jelent a Solidago gigantea, a Phragmites australis és az Ononis spinosa terjedése, megállíthatatlannak tünik a gyomosodás. Látszik, hogy valamiféle bolygatás történt a múltban, melynek hatásai ma is érzékelhetők.

\section{Lápi magaskórósok (D5)}

Környezetéből kimagasodó 1-2m magas, üde jellegű, kétszikűekben gazdag élőhelytípus. Leggyakoribb fajai a Filipendula ulmaria, Cirsium rivulare, fiatal Salix cinereapéldányok, valamint a Phragmites australis, amely a Solidago gigantea-val egyetemben folyamatosan terjed. Helyenként megtalálható a Scirpus sylvaticus, Cirsium oleraceum, Carex acutiformis, Cornus sanguinea, míg gyakrabban a Calystegia sepium, Galium mollugo. Alacsonyabb gyepmagasságnál megjelenik a Phalaris arundinacea, Iris pseudacorus, Selinum carvifolia, Galium uliginosum, Lysimachia vulgaris is. Kissé magasabb részeken szárazodó állománya van jelen. Itt a Salix cinerea-sokaság kiritkul, kevesebb a Filipendula ulmaria, és megjelenik a Calamagrostis epigeios. A szomszédos lápréttel és kékperjéssel folyamatos átmenetet képez, így a fajok áthúzódnak egyik típusból a másikba. Ennek értelmében előfordul benne Veratrum album, Thelypteris palustris és csomókban Molinia coerulea is.
Efemer vízfolyások medrében, legalább 0,5-1 m szélességben, szalagszerüen, kissé alacsonyabb térszínen, üde termőhelyen, láprétekkel érintkezve is magaskórós jellegű állományok húzódnak. Itt alacsonyabb a gyepmagasság, mivel a magas növésü Filipendula ulmaria hiányzik. A korábban már említett fajok kiegészülnek a Cirsium canum, Eupatorium cannabinum, Epilobium hirsutum, Sonchus palustris, Lythrum salicaria, Mentha aquatica egyedeivel.

\section{Nyílt homokpusztagyepek (G1)}

Nagyon kis kiterjedésben, fragmentálisan, homoki sztyepprétekkel övezve található meg ez az élöhelytípus a területen. A környező zártabb gyeptípusnál (homoki sztyepprét) alacsonyabb borítású, ahol a nyílt homokfelszínek mellett igen gazdag a moha- és zuzmószint. Domináns faja a Festuca vaginata, további évelő füfajai a Stipa capillata, Phleum phleoides, Poa bulbosa, Carex liparicarpos, valamint helyenként a Bothriochloa ischaemum. Évelő kétszikü fajai a Potentilla arenaria, Alyssum tortuosum, Euphorbia seguieriana, Thymus sp, Medicago minima, Hieracium echioides, Artemisia campestris, Fumana procumbens, Petrorhagia saxifraga. Védett fajai az Allium sphaerocephalon, Centaurea arenaria, Helichrysum arenarium. A homoki gyepek közönséges fajai közül a Silene otites, S. conica, Allium flavum emelendő ki. Az Eryngium campestre jelenléte zavarást jelez, az Ailanthus altissima és a Robinia pseudoacacia terjedése pedig további veszélyeztető tényezőt jelent. Természetvédelmi szempontból negatívumként értékelhető továbbá a Conyza canadensis és az Ambrosia artemisiifolia egyes foltokban való nagyarányú előfordulása is.

\section{Homoki sztyepprétek (H5b)}

Homokbuckákon, humuszban gazdagabb homoktalajokon találkozhatunk különböző degradáltsági fokú, zárt homoki sztyepprétekkel. Ebben a gyeptípusban a Festuca rupicola, Koeleria cristata, Poa angustifolia dominál, míg a bolygatottabb, zavartabb részeken a Bothriochloa ischaemum. Helyenként az erre a típusra igen jellemző Chrysopogon gryllus, Stipa capillata, vagy Asparagus officinalis egyedei emelkednek ki a közel azonos magasságú gyepből. További sás- és füfajai a Carex praecox, C stenophylla, C. liparicarpos, C. supina, C. caryophyllea, Anthoxanthum odoratum, és a Briza media. A füféléknél alacsonyabb tőszámmal igen sokféle kétszikü fordulhat elö, ami szinte végtelen fajgazdagságot kölcsönöz e gyepeknek. Gyakori az Achillea collina, Euphorbia cyparissias, Teucrium chamaedrys, Erysimum diffusum, Galium verum, Filipendula vulgaris, különösen a buckatalpakhoz közel a Salvia pratensis. Ritkábban fordul elö a Pulsatilla nigricans, Helichrysum arenarium, Allium sphaerocephalon, Anthyllis vulneraria, Polygala comosa, Ranunculus polyanthemos, Centaurea arenaria, Polygonum arenarium, Salsola kali, Plantago media, Artemisia campestris, Hieracium echioides, H. pilosella, Gypsophila paniculata, Luzula campestris, Colchicum autumnale. Alacsonyabb térszínen az Orchis morio, Equisetum moorei, Peucedanum oroselinum is megtalálható. Nyíltabb foltokon Alyssum tortuosum, Allium 
1. táblázat. Az élöhelyfoltok területi megoszlása.

\begin{tabular}{|l|r|}
\hline \multicolumn{1}{|c|}{ Élöhelytípus (ÁNÉR) } & \multicolumn{1}{c|}{ Terület (ha) } \\
\hline Zsombékosok & 0,1395 \\
\hline Nem zsombékoló magassásrét & 3,7665 \\
\hline Meszes láprét & 1,4913 \\
\hline Kiszáradó láprét & 19,8041 \\
\hline Mocsárrét & 1,6641 \\
\hline Lápi magaskórós & 0,8048 \\
\hline Nyílt homokpusztagyep & 0,3014 \\
\hline Homoki sztyepprét & 67,8463 \\
\hline Jellegtelen üde gyepek, magaskórósok & 7,6831 \\
\hline Jellegtelen száraz, félszáraz gyepek & 1,5887 \\
\hline Lágyszárú özönfajok állományai & 16,8988 \\
\hline Üde és nedves cserjések & 7,5577 \\
\hline Öshonos fafajú facsoportok, fasorok & 7,2331 \\
\hline Jellegtelen puhafás és pionír erdők & 44,38 \\
\hline Vegyes erdők & 15,3694 \\
\hline Akácültetvények & 7,0938 \\
\hline Telepített erdei ésfeketefenyvesek & $\mathbf{2 2 1 , 9 1 1 9}$ \\
\hline Nem őshonos fafajok spontán állományai & 9,4746 \\
\hline Extenzív szántó & 5,0674 \\
\hline Tanyák, családi gazdaságok & 1,2857 \\
\hline Úthálózat & 0,5784 \\
\hline Összesen & 1,8832 \\
\hline
\end{tabular}

Megjegyzések: (1) A meszes és kiszáradó láprétek, valamint a jellegtelen puhafás vagy pionír erdők esetében a számolt terület az ide tartozó átmeneti, vagy finomabb kategóriák területét is tartalmazza. (2) A Látrányi Puszta TT. összterülete pontosan 220,6927 hektár. A számolt értékben való eltérés valószínüleg a rajzolás okozta pontatlanságnak tudható be, azonban a hiba 0,5\%-os, így elhanyagolható.

flavum, Thymus sp., Euphorbia seguieriana és Potentilla arenaria jelenik meg a Festuca-csomók között. A buckatetőkön, feltehetően a helyi kilúgzódás miatt savanyúbb homokon Rumex acetosella, Danthonia decumbens és Hypochoeris radicata is előfordul. A kiszáradó láprétek fajai is felkúszhatnak a lankásabb buckaoldalakra, ahol kissé nedvesebbek a körülmények. A Frangula alnus, Holcus mollis, Carex hirta, Centaurea pannonica syn. C. jacea ssp. angustifolia és Serratula tinctoria jelenléte jól jelzi mindezt. Gyakran Crataegus monogyna-val, Prunus spinosa-val való cserjésedés figyelhető meg. Az egykoron legeltetett részeken viszonylag sok a tövises növény (Ononis spinosa, Eryngium campestre) a gyepszintben is. Helyenként a Solidago gigantea, S. canadensis és a Calamagrostis epigeios is jelen van.

\section{Jellegtelen üde gyepek és magaskórósok (OB)}

Üde vagy nedves termőhelyi körülmények között kialakult élőhelyfoltok tartoznak ide, amelyek természetes élőhelytípusba nem sorolhatók be, mivel fajkészletük jellegtelen, gyomos, kevert vagy degradált (BöLöNI et al 2011). Látrányban egy a terület keleti oldalán található, felülvetett mocsárrétet, illetve egy jellegtelen üde magaskóróst tekintettünk ide tartozónak. Előbbi esetében a felülvetés Medicago sativa és Festuca pratensis keverékével történt. Rendszeres kaszálással hasznosítják. A vetett, értelemszerüen tömeges fajok mellett számtalan kétszikủ alkotja a gyepet, amelyek közt föként nedves réti illetve indifferens fajok vannak. Az egész folt nem egységes, ami a tulajdonviszonyokra vezethető vissza, illetve arra, hogy más tulajdonos más módon gazdálkodott (vagy gazdálkodik) a területén. A kissé diverzebb déli részen a Festuca pratensis mellett Molinia coerulea, Succisa pratensis, Ranunculus acris, Daucus carota, Plantago lanceolata, Betonica officinalis, Sanguisorba officinalis, Lythrum salicaria, Cirsium canum és Lychnis flos-cuculi fordult elö. Érdekesség, hogy az elsősorban kiszáradó láprétekre jellemző Dianthus superbus több száz tőre tehető állománnyal volt jelen a területen. A másik, magaskórós jellegü élőhelyfolt a Visz községet Látránnyal összekötő út mellett található, egy árokszerü mélyedésben, alacsonyabb térszínen. Domináns faja a Solidago gigantea, azonban még nyomokban felfedezhetők benne a magaskórósok fajai. Az említett inváziós növény mellett Galium palustre, Phragmites australis, Filipendula ulmaria és nagy mennyiségű Calystegia sepium is elöfordult. 


\section{Jellegtelen száraz-félszáraz gyepek (OC)}

Az előző felmérés óta a terület középső és északi részén akkor parlagnak besorolt élöhelyek jellegtelen száraz, félszáraz gyepekké, óparlagokká „fejlődtek”. Gyomosak, jellegtelenek, látszanak rajtuk bolygatás nyomai. Fajkészletük zömmel indifferens fajokból áll. Leggyakrabban Calamagrostis epigeios, Dipsacus laciniatus, Ambrosia artemisiifolia, Cirsium canum, Achillea collina, Centaurea pannonica, Rumex acetosella, Conyza canadensis, Daucus carota, Berteroa incana, Plantago lanceolata, Verbascum phlomoides, Galium verum, Solidago gigantea előfordulása volt jellemző.

\section{Lágyszárú özönfajok állományai (OD)}

A vizsgált területen a Solidago gigantea terjedése okozza a legnagyobb problémát. Ilyen élőhelyeknek azokat az erősen gyomosodott állományokat tekintettük, ahol az inváziós növény nagyfokú dominanciája volt megfigyelhető. Az ide tartozó területek igénylik a legsürgősebb természetvédelmi célú beavatkozást, kezelést.

\section{Üde és nedves cserjések (P2a)}

Ez a növényzeti típus elsősorban illegális homokbányászat által bolygatott területen alakult ki. Valaha homoki sztyepprétek voltak itt jellemzőek, azonban a homok kinyerésével alacsonyabb térszín jött létre, ahol csapadékosabb években a víz megáll. Fiatal, alacsony termetü, pionír Pinus sylvestris, Betula pendula, Populus alba, Cornus sanguinea, Salix alba, S. purpurea, S. cinerea, Frangula alnus, és Viburnum opulus alkotják a viszonylag sürü cserjés részeket. A szárazabb helyeken a Cornus sanguinea mellett a Crataegus monogyna dominál. A magasabb, kissé szárazabb térszíneken ligetes jellegü állományt alkotnak a cserjék, és a szomszédos sztyepprétekkel finoman mozaikolnak. Más esetekben gyepszintjük meglehetősen gyér. Az alacsonyabb részeken a Salix-fajok dominálnak, a mohaszint fejlett, amelyet közönséges lombosmoha fajok alkotnak. Megjelenik a Phragmites australis is, azonban nem alkot zárt állományokat. Azokon a részeken, amelyek magassásréttel határosak, a Salix cinerea a legjellemzőbb fás szárú faj. Kis területen tőzegképződés is zajlik, ezt jelzi a cserjék alatt helyenként megtalálható Thelypteris palustris. A típus nagyobb állománya található meg a terület északi részén, nedves rétek szukcessziójának köszönhetően, részben azokkal mozaikolva. A bekötőút kanyarulatától keletre eső folt éger-telepítés eredménye, az éger (Alnus glutinosa) egyedek még nem érték el a fatermetet.

\section{Öshonos fajú facsoportok, fasorok, erdősávok (RA)}

Ide tartoznak azok a kisebb, fásszárúakból álló állományok, amelyek már nem tekinthetők magányos fáknak, de még nem záródtak erdővé sem (BöLöNI et al. 2011). Elsősorban őshonos, puhafákból álló, többnyire ültetett fasorok, vagy spontán kialakult facsoportok sorolhatók ebbe a kategóriába a területen. A fák alatt a cserje- és gyepszint jellegtelen.

\section{Öshonos fafajú puhafás jellegtelen, vagy pionír erdők (RB)}

Jellegtelen állományok, amelyek természetes úton, spontán erdősülés során alakulnak ki, azonban ide sorolandók a jellegtelen aljnövényzetű telepített égeresek is. A lombkoronaszint fajkészlete rendkívül kevert, ahol az őshonos puhafák dominanciája figyelhető meg. Előfordulhatnak benne pionír és tájidegen fajok is. Leggyakrabban Betula pendula, Pinus sylvestris, Populus alba, $P$. nigra, $P$. tremula, $P$. $x$ canescens, Salix alba, S. cinerea, S. fragilis alkotják. Helyenként megjelenik a Robinia pseudoacacia, Ailanthus altissima, Acer negundo, Alnus glutinosa, vagy az Acer pseudoplatanus is. A szántó környezetében húzódó foltjában egy valaha volt jobb erdőállomány nyomait őrzi egy-egy példány Quercus robur, Pyrus pyraster, Cerasus avium. A cserjeszintet föleg Cornus sanguinea, a széleken, ahol szárazabb a termőhely Crataegus monogyna, Prunus spinosa alkotja, de elöfordulhat Frangula alnus, Euonymus europaeus, Ligustrum vulgare, Rosa canina, Sambucus nigra, Corylus avellana is. A gyepszint jellegtelen, sok generalista fajjal. Solidago gigantea-val erősen fertőzött. Vannak erősen ligetes állományai is, ahol a szomszédos szárazabb gyeppel mozaikol. Alacsonyabban fekvő állományaiban megjelennek az inkább nedvesebb élőhelyeket kedvelö, kórós megjelenésü fajok is, mint az Equisetum telmateia, Lythrum salicaria, Sonchus palustris, Epilobium hirsutum, Valeriana officinalis vagy a generalista Artemisia vulgaris, Heracleum sphondylium, Urtica dioica, Phragmites australis, Calamagrostis epigeios.

A csoporton belül kiemelten ábrázoltuk a jellegtelen aljnövényzetü telepített égereseket. A lombszintben nagyrészt csak az Alnus glutinosa fordul elő, néhol azonban a Robinia pseudoacacia és az Ailanthus altissima is behúzódik az állományokba. Cserjeszintjében Rubus fruticosus képezhet áthatolhatatlan tömeget. A Solidago gigantea többnyire szegélyt alkotva fordul elő, mellette kevés lágyszárú figyelhető csak meg az aljnövényzetben: Scirpoides holoschoenus, Carex acutiformis, kora tavasszal néhány tő Corydalis solida, később az Epilobium hirsutum néhány példánya. A védett Equisetum hyemale, valamint az E. ramosissimum és kettejük hibridje, a hatályos jogszabályok szerint szintén védett, $E$. moorei is előfordult ilyen állományban. Utóbbira jellemző a legnagyobb részarány, jelentős állománya homoki sztyepprétekbe is áthúzódik.

\section{Öshonos lombos fafajokkal elegyes idegenhonos lombos, vegyes erdők (RDb)}

Ezt a kategóriát gyűjtőcsoportnak tekintettük és ide soroltuk be azokat az erdőrészleteket, amelyekben keményfák, puhafák, tájidegen és adventív fajok együtt fordultak elő. Erdészeti üzemtervek szerint az ábrázolt foltban Alnus glutinosa, Acer platanoides, Tilia tomentosa, Robinia pseudoacacia, Pinus sylvestris, Pinus nigra, Ailanthus altissima, Quercus robur található. Aljnövényzetük fajszegény, a zártabb, elegyetlen állományoké szinte nudum. 


\section{Akác ültetvények (S1)}

Az akác ültetvény kategóriába az elegyetlen, idősebb akáctelepítések kerültek, melyek a terület délidélnyugati oldalán találhatók. Szomszédságukban a faj spontán terjedése figyelhető meg.

\section{Ültetett erdei és feketefenyvesek (S4)}

Elegyetlen állományai a terület nyugati, délnyugati részén találhatók, máshol valamilyen lombos fafajjal elegyesen fordul elő valamelyik tülevelű faj. Aljnövényzetük szegényes, de őrzi még a homokpuszták nyomát, hiszen előfordul bennük a Carex liparicarpos, Festuca vaginata, Euphorbia seguieriana, Hieracium echioides, néhány tő Juniperus communis, a frissen bolygatott, nyíltabb helyeken Kochia laniflora és a védett, a területröl új florisztikai adatként szereplö Onosma arenaria is. Ezen kívül olyan közönséges fajok is megtalálhatók, mint az Elymus repens, Calamagrostis epigeios, Dactylis glomerata, valamint az üdébb helyeket kedvelö Dryopteris filix-mas is. Természetvédelmi szempontból problémát jelent, hogy Ailanthus altissima-val erősen fertőzöttek.

\section{Nem őshonos fafajok spontán állományai (S6)}

A nem őshonos fafajok spontán állományai általában az ültetett állományok magszórásának köszönhető spontán terjedés következtében jöttek létre, többnyire az ültetvényekhez közel. A vizsgált területen a Robinia pseudoacacia és Ailanthus altissima állományok tartoznak ebbe a csoportba.

\section{Extenzív szántók (T6)}

A védett területen egyetlen olyan mezőgazdasági terület van, amelyet rendszeresen müvelnek. Ez egy 1,2 hektáros szántóterület, ahol a tulajdonos extenzív módon gazdálkodik

\section{Tanyák, családi gazdaságok (U10)}

A területen található malom és az egykori mérlegház 0,5 hektárnyi területét rögzítettük ebben a csoportban.

\section{Úthálózat (U11)}

Ebbe a kategóriába a Visz községet Látránnyal öszszekötő aszfaltozott utat soroltuk, a keskenyebb földutakat nem jelöltük a térképen. Ide tartozóként rögzítettük a keskeny útszéli gyomvegetációt, mivel annak szélessége nem érte el az ÁNÉR szerint elöírt rögzítési minimumot.

A terepbejárások során a vizsgált területen összesen 241 növényfaj előfordulását állapítottuk meg (1. melléklet). Ezek között a hatályos jogszabály alapján 22 védett faj található: Allium sphaerocephalon, Carex paniculata, Centaurea arenaria, Cirsium rivulare, Dactylorhiza incarnata, Dianthus superbus, Eleocharis uniglumis, Epipactis palustris, Equisetum hyemale, Equisetum moorei, Eriophorum angustifolium, Eriophorum latifolium, Helichrysum arenarium, Onosma arenaria, Orchis morio, Orchis palustris, Parnassia palustris, Pulsatilla nigricans, Schoenus nigricans, Sonchus palustris, Thelypteris palustris, Veratrum album.

\section{Következtetések}

$A z$ élöhelytérképezés eredményeiből látszik, milyen nagymértékủ a változatosság a területen, hiszen 220,7 hektáron 26 különböző élőhelytípust sikerült kimutatnunk 94 élőhelyfoltban (foltcsoportban). A lehető legnagyobb részletességre törekedtünk, mivel a vizsgált terület legjelentősebb természeti értékei a legkisebb, ritka élőhelyfoltokban rejlenek. Mivel sok ritka, védett faj találja meg az életfeltételeit itt, ezért fontos ezeknek a kis fragmentumoknak a rögzítése is. A természetvédelmi szempontból értékesebb élőhelyek viszont nagyon érzékenyek, így fontos feladat fenntartásuk akár aktív beavatkozással is. Nedvesebb termőhelyeken a vízellátás sérülése, megszűnése, így a kiszáradás, míg szárazabb termőhelyeken inkább az emberi behatások okozta jellegtelenné válás a legveszélyeztetőbb tényező. $A z$ egész területen problémát jelent az agresszív, inváziós gyomnövények terjedése (Solidago gigantea, Ailanthus altissima, Robinia pseudoacacia, kisebb mértékben az Asclepias syriaca), amely ellen a lehető leggyorsabban be kellene avatkozni.

A Látrányi Puszta élőhelyei közül a fátlan típusok azok, amelyek kiemelt figyelmet érdemelnek. A legnagyobb területarányt a homoki sztyepprétek képviselik, a nyílt homokpusztagyepek viszont csak igen kis területen vannak jelen. Mindez az élőhely országos helyzetét is reprezentálja. A természetes, nedves gyepi élőhelyek közül a leggyakoribbnak a kiszáradó láprét tekinthetö, míg a zsombékosok csak igen kis kiterjedésben, fragmentálisan találhatók. A legnagyobb természetvédelmi értéket a közel 1,5 hektár területű meszes láprétek jelentik. Az említett élöhelyek egymáshoz viszonyított aránya jól tükrözi a termőhelyek állapotát, vízellátottságát, így hosszú távú termőhelyi változások is nyomon követhetők. Ennek jó indikátora lehet akár a Schoenus nigricans is. Érdekes és érdemes lenne megfigyelni, hogy hogyan változik a növény által kirajzolt foltok mérete az idők során. Jelenleg pillanatnyi állapotot ábrázoltunk, azonban ezeknek az élőhelyeknek dinamikája van. A foltok méretének növekedése, csökkenése, vagy a fajösszetétel és a dominanciaviszonyok változása jól jelezhetné számunkra a változásokat. További, indikátorként is viselkedő, domináns fajok állománynagyságának hosszú távú vizsgálata sokat mondhatna a környezeti adottságok változásairól.

Felmérésünk során a növényzet aktuális állapotát rögzítettük. Mivel az 1996-2002-es vizsgálat során a szerző más kategóriarendszerrel dolgozott - az ÁNÉR később került kidolgozásra - így érdemi, számadatokkal is alátámasztható összehasonlítás nem tehető a növényzeti változásokat illetően. Munkánk ugyanakkor megteremtette egy későbbi, azonos (standard) kategóriarendszert alkalmazó kutatás eredményeivel való öszszevetés (long term monitoring) lehetőségét.

\section{Köszönetnyilvánítás}

Köszönetünket szeretnénk kifejezni Rozner Györgynek és Dr. Lanszki Józsefnek a térinformatikai eszköz-, szoftver- és tudásháttér megteremtéséért. 


\section{A LÁTRÁNYI PUSZTA TERMÉSZETVÉDELMI TERÜLET AKTUÁLIS VEGETÁCIÓTÉRKÉPE}

\section{Irodalom}

ÁbrahÁm L. (szerk.) 2003: A Látrányi Puszta Természetvédelmi Terület élővilága. - Natura Somogyiensis 5. Kaposvár

Bartha S., Balogh L., Biró M., Bódis J., Csete S., Csiky J., Fráter E. Hayek Zs., Lájer K., Purger D. és Szigetvári Cs. 2006: Nyílt és záródó homokpusztagyepek társulási viszonyainak összehasonlítása a vácrátóti Tece legelön. In: Molnár, E. (szerk.) Kutatás, oktatás, értékteremtés. - MTA Ökológiai és Botanikai Kutatóintézete, Vácrátót, pp. 111-132.

BoRHIDI A. 2003: Magyarország növénytársulásai. - Akadémiai Kiadó, Budapest pp.86-258.

BöLöNI J., MoLnÁR Zs. és Kun A. (szerk.) 2011: Magyarország Élöhelyei. Vegetációtípusok leírása és határozója, ÁNÉR 2011. - MTA Ökológiai és Botanikai Kutatóintézete, Vácrátót

DeBreczY Zs. 1981: Növényvilág a Balaton körül. In: Illés I. (szerk.): Tavunk, a Balaton. - Natura Kiadó, Budapest pp.75-119.

DövéNYI Z. (szerk.) 2010: Magyarország kistájainak katasztere. - MTA Földrajztudományi Kutatóintézet, Budapest pp. 439-441.

IHRIG D. (szerk.) 1973: A magyar vízszabályozás története. - Országos Vízügyi Hivatal, Budapest

KIRÁlY G. (szerk.) 2009: Új magyar füvészkönyv. - Aggteleki Nemzeti Park lgazgatóság, Jósvafö

KovÁcs, M. 1955: Die zönologischen und ökologischen Verhaltnisse von Cladietum marisci in der gegend des Balaton-Sees. - Acta Botanica Hungarica 2/1-2: 133-146.

KovÁcs M. 1958: Magyarország láprétjeinek ökológiai viszonyai (Talajmikroklíma viszonyok). - Magyar Tudományos Akadémia Biológiai Csoportjának Közleményei 1: 387-454

LAJER K. 1998/a: Bevezetés a magyarországi lápok vegetációökológiájába. - Tilia 6: 84-238

LÁJER K. 1998/b: Újabb adatok Belső-Somogy flórájának és vegetációjának ismeretéhez. - Somogyi Múzeumok Közleményei 13: 217-239.

LAJER K. 1998/c: Az Aldrovanda vesiculosa L. újabb elöfordulása és egyéb adatok Magyarország flórájának ismeretéhez. - Kitaibelia III/2: 263-274
LÁJeR K. 2003: A Látrányi Puszta Természetvédelmi Terület növényzetéröl. - Natura Somogyiensis 5: 13-28.

LÁJER K. 2006: A kormos csáté társulási viszonyairól Magyarországon. Flora Pannonica 4: 77-90.

LenDVAI G. 1990: A Tengelici-homokvidék északi részének vegetációja. Botanikai Közlemények 77/1-2: 9-16.

MAROsı S. (szerk.) 1990: Magyarország kistájainak katasztere. - MTA Földrajztudományi Kutatóintézet, Budapest.

Molnár, Cs., Molnár, Zs., Barina, Z., Bauer, N., Biró, M., Bodonczi, L., Csathó, A.I., Csiky, J., Deák, J.Á., Fekete, G., Harmos, K., Horváth, A., Isépy, l., Juhász, M., Kállayné Szerényi, J., Király, G., Magos, G. Máté, A., Mesterházy, A., Molnár, A., Nagy, J., Óvári, M., Purger, D., Schmidt, D., Sramkó, G., Szénásı, V., Szmorad, F., Szollát, Gy., TÓTH, T., VIDRA, T. \& VIRÓK, V. 2008: Vegetation-based landscape regions of Hungary. - Acta Botanica Hungarica 50: 47-58.

MolnáR, Zs., BIRó, M., BölŌNI, J. \& HoRVÁtH, F. 2008/a: Distribution of the (semi-) natural habitats in Hungary I. Marshes and grasslands. Acta Botanica Hungarica 50: 59-105.

Molnár Zs., Fekete G., Biró M. és Kun A. 2008/b: A Duna-Tisza közi homoki sztyepprétek történeti, tájökológia jellemzése. In: Kröel-Dulay Gy., Kalapos T., Mojzes A. (szerk.): Talaj-vegetáció-klíma kölcsönhatások. Köszöntjük a 70 éves Láng Editet. - MTA Ökológiai és Botanikai Kutatóintézete, Vácrátót, pp. 36-59.

RozNer GY., Mıókovics E. és VIDÉkı R. 2011: Védett növényfajok elöfordulási adatai Észak-Somogyban. - Natura Somogyiensis 19: 5-26.

SzaLóky I. és Bódis J. 2004: A Lellei-Bozót és a Szemesi-Berek élőhelyei. - Somogyi Múzeumok Közleményei 16: 279-290.

ZıINSZKY A. 2011: A Balaton és a környezö mocsarak történelmi rekonstrukciója térinformatikai módszerekkel. - A Balaton ökológiája, Magyar Tudományos Akadémia, Balatoni Limnológiai Kutatóintézet elektronikus folyóirata 1: 49-60.

\section{1. melléklet. A vizsgált területen elöfordult növényfajok listája.}

Acer campestre
Acer platanoides
Acer negundo
Acer pseudoplatanus
Achillea asplenifolia
Achillea collina
Aegopodium podagraria
Agrostis alba
Agrimonia eupatoria
Ailanthus altissima
Allium angulosum
Allium flavum
Allium sphaerocephalon
Allium vineale
Alnus glutinosa
Alyssum tortuosum
Ambrosia artemisifolia
Angelica sylvestris
Anthoxanthum odoratum
Anthyllis vulneraria
Arctium lappa
Artemisia campestre
Artemisia vulgaris
Asclepias syriaca

Acer campestre

Acer platanoides

Acer negundo

Achillea asplenifolia

Achillea collina

Aegopodium podagraria

Agrostis alba

Agrimonia eupatoria

Ailanthus altissima

Allium sphaerocephalon

Allium vineale

Alnus glutinosa

issum tortuosum

Angelica sylvestris

Anthoxanthum odoratum

Anthyllis vulneraria

Arctium lappa

Artemisia vulgaris

Asclepias syriaca

Asparagus officinalis
Astragalus cicer
Berteroa incana
Betonica officinalis
Betula pendula
Bothryochloa ischaemum
Brachypodium pinnatum
Briza media
Bromus squarrosus
Calamagrostis epigeios
Calystegia sepium
Carex acutiformis
Carex caryophyllea
Carex elata
Carex flacca
Carex flava
Carex hirta
Carex hostiana
Carex liparicarpos
Carex panicea
Carex paniculata
Carex praecox
Carex riparia
Carex stenophylla

Carex supina

Carex vulpina

Carduus nutans

Carlina vulgaris

Centaurea arenaria

Centaurea pannonica

Cerasus avium

Chelidonium majus

Chenopodium album

Chrysopogon gryllus

Cichorium intybus

Cirsium arvense

Cirsium canum

Cirsium oleraceum

Cirsium palustre

Cirsium rivulare

Cladium mariscus

Colchicum autumnalis

Conyza canadensis

Cornus sanguinea

Corydalis solida

Corylus avellana

Crataegus monogyna

Cruciata laevipes
Cynodon dactylon

Dactylis glomerata

Dactylorhiza incarnata

Danthonia decumbens

Daucus carota

Deschampsia caespitosa

Dianthus pontederae

Dianthus superbus

Dipsacus laciniatus

Dryopteris filix-mas

Eleocharis uniglumis

Elymus hispidus

Elymus repens

Epilobium hirsutum

Epipactis palustris

Equisetum hyemale

Equisetum moorei

Equisetum palustre

Equisetum ramosissimum

Equisetum telmateia

Eringium campestre

Eriophorum angustifolium

Eriophorum latifolium

Erysimum diffusum 
Euonymus europaeus

Eupatorium cannabinum

Euphorbia cyparissias

Euphorbia segueriana

Euphorbia villosa

Festuca pratensis

Festuca rupicola

Festuca vaginata

Filipendula ulmaria

Filipendula vulgaris

Fragaria viridis

Frangula alnus

Fraxinus excelsior

Fumana procumbens

Galium aparine

Galium mollugo

Galium palustre

Galium verum

Glechoma hederacea

Gypsophila paniculata

Helianthemum ovatum

Helichrysum arenarium

Heracleum sphondylium

Hieracium echioides

Hieracium pilosella

Holcus mollis

Humulus lupulus

Hypericum perforatum

Hypocoeris radicata

Iris pseudacorus

Juglans regia

Juncus articulatus

Juncus effusus

Juncus inflexus

Juncus subnodulosus

Juniperus communis

Kochia laniflora
Koeleria cristata

Knautia arvense

Lathyrus tuberosa

Ligustrum vulgare

Linaria vulgaris

Lotus siliquosus

Lotus corniculatus

Luzula campestris

Lychnis flos-cuculi

Lycopus europaeus

Lysimachia vulgaris

Lythrum salicaria

Medicago falcata

Medicago minima

Medicago sativa

Mentha aquatica

Molinia arundinacea

Molinia coerulea

Muscari comosum

Oenothera biennis

Ononis spinosa

Onosma arenaria

Orchis morio

Orchis palustris

Parnassia palustris

Petrorhagia saxifraga

Peucedanum oroselinum

Phalaris arundinacea

Phleum phleoides

Phragmites australis

Pinus nigra

Pinus sylvestris

Plantago lanceolata

Plantago media

Poa angustifolia

Poa bulbosa

Polygala comosa
Polygonum arenarium

Populus alba

Populus $x$ canescens

Populus nigra

Populus nigra cv. italica

Populus tremula

Potentilla anserina

Potentilla arenaria

Potentilla erecta

Prunus spinosa

Pseudolysimachion spicata

Pulicaria dysenterica

Pulsatilla nigricans

Pyrus pyraster

Quercus robur

Ranunculus acris

Ranunculus polyanthemos

Rhamnus catharticus

Robinia pseudoacacia

Rosa canina

Rubus caesius

Rubus fruticosus

Rumex acetosella

Salix alba

Salix cinerea

Salix fragilis

Salix purpurea

Salsola kali

Salvia pratensis

Sanguisorba officinalis

Sambucus ebulus

Sambucus nigra

Saponaria officinalis

Schoenus nigricans

Scirpoides holoschoenus

Sedum acre ssp. acre

Selinum carvifolium
Senecio integrifolius

Serratula tinctoria

Seseli annuum

Setaria viridis

Silene conica

Silene otites

Silene vulgaris

Sisymbrium altissimum

Solanum dulcamara

Solidago canadensis

Solidago gigantea

Sonchus palustris

Stipa capillata

Succisa pratensis

Symphytum officinalis

Teucrium chamedrys

Thelypteris palustris

Thesium lynophyllum

Thymus sp.

Tilia platyphyllos

Tragopogon pratensis ssp.

orientalis

Trifolium arvense

Typha angustifolia

Ulmus minor

Urtica dioica

Valeriana dioica

Valeriana officinalis

Veratrum album

Verbascum phlomoides

Verbascum lychnitis

Veronica prostrata

Viburnum opulus

Vicia cracca

\section{Actual Vegetation Map of Látrányi Puszta Nature Conservation Area (Hungary)}

\section{KRISZTINA SOVÁNY, GYÖRGY SZOLLÁT \& MAGDOLNA JUHÁSZ}

The Látrányi Puszta Nature Conservation Area, situated near Lake Balaton and protected since 1992 is the object of this study. Its botanical values are really unique.

Creating of a very particular and GIS-based vegetation map of the surveyed area were topical for the nature conservation. The previous vegetation map, made between 1996-2002, served as adequate basis to work out the management plan, however, needed an updating yet. The aim of this study is to make up this shortage.

The current condition of vegetation and flora of the Nature Conservation Area were recorded during our work, using the available modernest GPS-technique, GIS-software and the latest list of General National Habitat Classification System (ÁNÉR 2011), thus the bases of comparability and reproduction were founded for future researches.

As a main result of the survey 26 several habitats were detected in 94 vegetation patches or patch-groups. Mostly the woodless habitats are the notablest ones, like rich fens, open sand steppes or some more natural stands of closed sand steppes. These are very rare in the Southern-Transdanubia, and even in Hungary as well. Many protected plant species (Dianthus superbus, Eriophorum latifolium, Eriophorum angustifolium, Parnassia palustris, Epipactis palustris, Thelypteris palustris, Allium sphaerocephalon, Onosma arenaria) find their living conditions here. 